$$
\text { zag. J. Pharm. Sci., Vol. 1, No.(1-2), Nov. } 1992
$$

\title{
MACRO - AND MICROMORPHOLOGY OF THE LEAF, STEM AND ROOT OF AMARANTHUS CHLOROSTACHYS WILLD
}

\author{
Taha M. Sarg , Ehsan M. Abd ALl-Aziz, Salem A. Salem \\ Department of Pharmacognosy, Faculty of Pharmacy, \\ University of Zagazig, Egypt
}

\section{ABSTRACT}

A study of the macro - and micromorphology of the leaf, stem and root of Amaranthus chlorostachys willd is presented with the aim of finding the diagnostic characters of these organs by which the plant could be easily identified both in the entire and powdered forms.

\section{INTRODUCTION}

Amaranthus chlorostachys willd, Family Amaranthaceae is a herbaceous plant growing wild in Nile-Delta of Egypt ${ }^{(1)}$. Some plants of Amaranthus species are used in folk medicine as diuretic, antirheumatic, strengthen the liver, control haemorrhage caused by abortion and externally used as an ointment for boils and itches (2).

Phytochemical study of the plant led to the isolation and characterisation of 13 compounds ; lupeol, lupeol acetate, $\alpha$ - spinasterol, and two esters from the light petroleum extract.In addition, $\alpha$ spinasterol glucoside and $\beta$-sitosterol glucoside from the chloroformic extract. Quercetin and rutin also have been isolated from the ethyl acetate extract. Column chromatography of the aqueous extract led to the isolation and identification of two - spinasterol saponin glycosides, choline and some other basic nitrogenous substances ${ }^{(3)}$.

Nothing was reported in literature concerning the macro - and micromorphology of the plant except few data given by some floras $(1,4)$.

In this study, the macro - and micromorphology of the leaf, stem and root of the plant are presented with the aim of finding out the diagnostic characters by which the plant could be identified both in the entire and powdered forms. 


\section{EXPERIMENTAL}

Pant asterial Prech samples of Amaranthus chlorostachys Willd, vere follected from fowering plants growing wild in a region $20 \mathrm{~km}$ west of Zsupare during tuly 1989 and July 1990 . Authenticity of the plant was tmdly wentied ty Prof. Dr. Louty Boulos, National Research Center, Calra, Esypt

\section{A. Macromorphology :}

Amaranthue chlorostachys willd (Fig . I,A) is a herbaceous plant with alformate, lanceolste green leaves, showing cylindrical stems which carty tumetous terminal dense spikes and few small axillary ones meluding intermixed male and female flowers. The plant measures 2 to 3 In in height and flowering from July to september.

The leaves (Fig , 1,b)) are simple, petiolate, exstipulate, alternate "phyllotaxis $2 / 5 "$, green and hairy with pimately reticulate venation. The lamina is oval = lanceolate, with entire margin, symmetric base, acute to subacute apex, green surface and long petiole. It measures 3 to $10 \mathrm{~cm} \mathrm{~L}$,
and 1.5 to $6 \mathrm{~cm} \mathrm{~B}$.

The petiole (Fig, I,B ) is concave on upperside with two lateral ridges, convex on lower one, green, hairy and measures 2 to $7 \mathrm{~cm} \mathrm{~L}$, and 0.5 to
$1.5 \mathrm{~mm} \mathrm{D}$,

The stem (Fig. 1,A) is erect, herbaceous, almost cylindrical and monopodially branched. It is solid with hairy pink to green surface. The internodes are 5 to $12 \mathrm{~cm} \mathrm{~L}$ and 0.5 to $1.5 \mathrm{~cm} \mathrm{D}$, the fresh stem is flexible white the dry breaks with a short fracture in the outer part, fibrous in the
inner

The root (Fig , I,C) is a fusiform tap root, bearing many lateral roots and rootlets .It measures 12 to $35 \mathrm{~cm} \mathrm{~L}$ and 0.5 to $3 \mathrm{~cm} \mathrm{D.} \mathrm{Externally,} \mathrm{it} \mathrm{is}$ yellowish with longitudenally wrinkled rough surface. The root has short fibrous fracture and a yellowish - white interior. 
2ag. J. Pharm. Sci., Voi. 1, No. (1-2), Nov. 1992

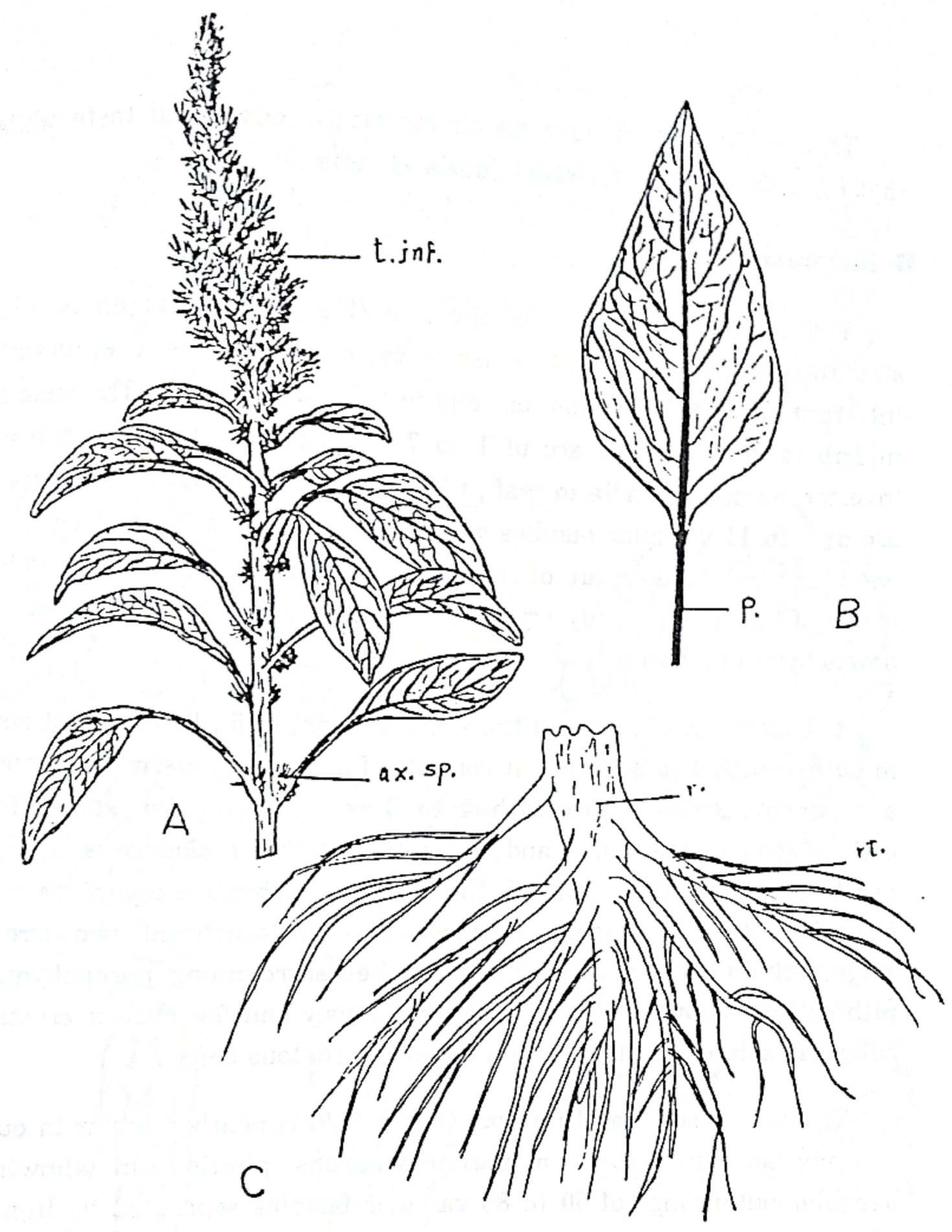

(Fig. 1) A- Sketch of Flowering top of Amaranthus chlorostachys Willd.

B- The leaf.

c- The root.

ax. axilary spike; P., petiole ; r., root ; rt., rootlet. t.Inf., terminal inflorescence.

(A $\times 0.8, \mathrm{~B} \times 0.8, \mathrm{C} \times 0.4$ ) 
The leaf and stem have no chancteristic odour and taste while the root has a faint characteristic odour and taste.

\section{8- Micromorphology :}

The transverse section of the leaf (Fig. 2,B) shows an isobilateral structure with one row of palisade cells beneath both epidermises, interrupted by collenchymatous cells in the midrib region. The stele of the midrib is formed of an arc of 1 to 7 vascular bundles with one upper inverted vascular bundle in leaf, while that of the petiole, consists of an arc of 4 to 11 vascular bundles with vascular bundle in each ridge. Each vascular bundle has an arc of collenchymatous pericycle below the phloem region. Cluster and sandy crystals of calcium oxalate are present in the parenchymatous cells.

The transverse section of the stem (Fig . 5, B, 6, B) is almost circular in outline with 4 to 8 ridges. It consists of an outer epidermis surrounding a parenchymatous cortex with 4 to 6 rows of angular subepidermal collenchyma in the ridges and well differentiated endodermis. The stele exhibits anomalous secondary thickening (5); shows a complete ring of irregular 13 to 44 vascular bundles and inner scattered two irregular rings including 23 to 52 vascular bundles surrounding parenchymatous pith with a hollow core in the old stem. Sandy and few cluster crystals of calcium oxalate are present in the parenchymatous cells .

Transverse section of the root (Fig. 8 \& 9) is nearly circular in outline showing an outer cork, a parenchymatous phelloderm showing 3 irregular outer rings of 60 to 85 vascular bundles separated by lignified cells and inner two irregular rings of 40 to 58 vascular bundles. In the center, there is a diarch lry xylem surrounded by a narrow secondary vascular tissue of an outer phloem and inner xylem, showing two wide parenchymatous primary medullary rays .The young root ( Fig . 8,B) shows a piliferous layer followed by a parenchymatous phelloderm, an endodermis and a parenchymatous pericycle enclosing diarch radial vascular bundles. 

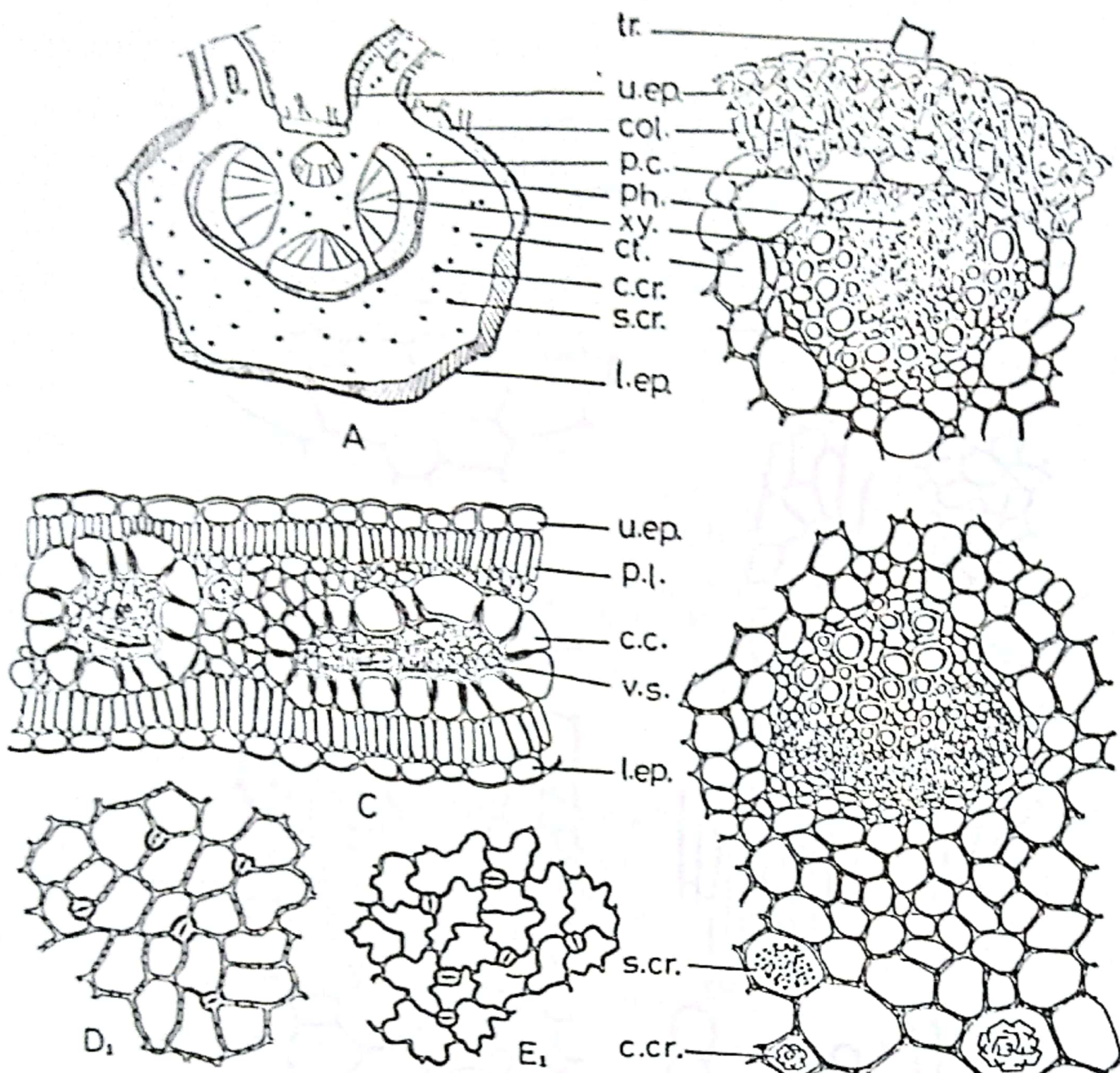

C
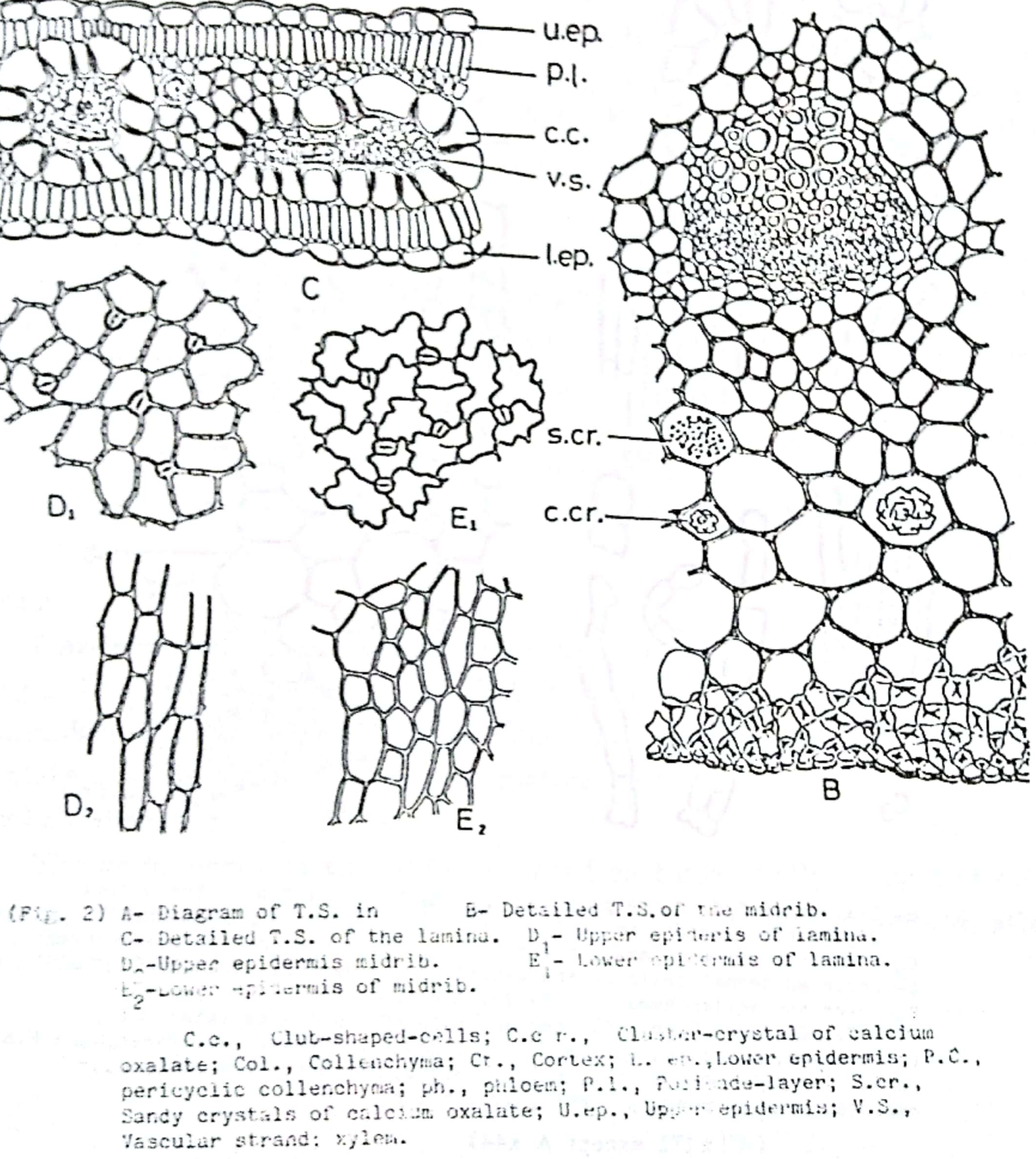

(All x324; except Ax 56, B\&C $\times 208$ ) 


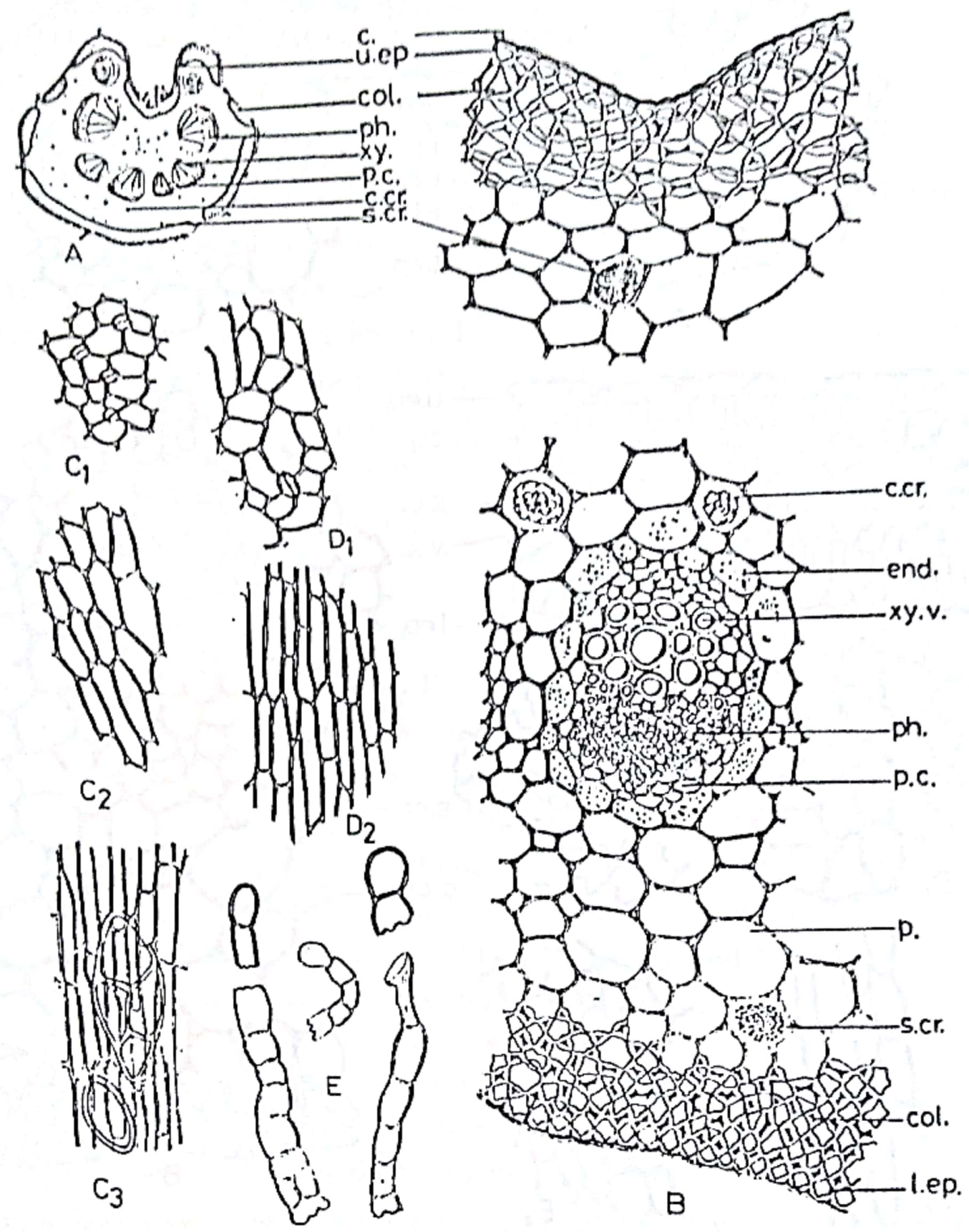

(Fig. 3) E- Diagram of T.S in the petiole.

C- Upper epidermis of the petiole

B- Detialed T.S. of the petiole Covier the firenchyma.

$C_{2}$ over the collenchyma of the ridks. aver the central collenchyma. $\mathrm{C}_{2}$ : lover the epidermal cells of the petiole $3_{\mathrm{b}}$;over the parenchyma $D_{2}$ :over the collenchyma E- Trianolnes.

c. Cuticle; C.cr., Cluster crystals of silciuin oxalate; Cò., Collenchyma; end., endodermis; L. Ev., Lower cpidermis, P., Parenchya; F.c., pericyclic collenchyma; ph., Phloeti; S.cr., surdy c:ystul of calcium oxalate; U.ep., Upper epiderris, xy., xylem.

(All $\times 172$ except $A \times 44)$ 
The Bpidermis

The epidermises of the lamina (Fig. 2, $\mathrm{D}_{1} \& \mathrm{E}_{1}$ ) consist of polygonal cells with wavy beaded anticlinal walls and covered with thin smooth cuticle. The epidermal cells of the petiole (Fig. 3,C \& D ), the neural regions, (Fig. 2, $\mathrm{D}_{2} \& \mathrm{E}_{2}$ ) and the stem (Fig. 5,C) are polygonal, axially elongated with thick outer periclinal walls, straight beaded anticlinal walls and covered with thin smooth cuticle. The dimensions of the epidermal cells are show in table (1).

Stomata : Are anomocytic, present on both surfaces of the lamina, being more on the lower, few are present on the surface of petiole and the stem (Fig . 2, D \& E, $3, \mathrm{C} \& \mathrm{D}, 5 \mathrm{C}_{1} \& \mathrm{C}_{2}$ ). They are oval or rounded in outline ,measuring 12 to $25 \mu \mathrm{L}$ and 10 to $20 \mu \mathrm{B}$.

Trichomes : ( Fig. 4 ,A \& 7,B ) .Both covering and glandular trichomes are present on surfaces of leaf, petiole, and stem. They are multicellular uniseriate formed of 8 to 19 cells with occasionally collapsed ones, occasional trichomes are biseriate or multiseriate with branched base and few collapsed cells. The glandular trichomes have unicellular heads measuring 16 to $36 \mu$ D.The cells have thin cellulosic walls and are covered with thin smooth cuticle. Trichomes measure 120 to $636 \mu \mathrm{L}$ and 10 to $33 \mu \mathrm{D}$.

\section{Cartex:}

The cortex of the midrib, the petiole (Fig. 2,B \& 3,B) and the stem (Fig.5 B \& 6 ,B) is parenchymatous with 4 to 6 rows of angular collenchyma in the ridges region. Sandy and cluster crystals of calcium oxalate are present in the parenchymatous cells.

\section{The Rndodermis :}

The endodermis is well differentiated as tangentially elongated cells contain starch granules in leaf and petiole, with pink pigments in stem and young root. 
Table (1): Dimensions of the epidermal cells of leaf and stem (in micron)

\begin{tabular}{|c|c|c|c|c|}
\hline Epidermis & "L" L & Length & "B" $\quad$ B & Breadth \\
\hline $\begin{array}{l}\text { Upper epidermis of } \\
\text { the lamina. }\end{array}$ & 20 & -42 & 16 & -28 \\
\hline $\begin{array}{l}\text { Lower epidermis of } \\
\text { the lamina. }\end{array}$ & 24 & -42 & 10 & -28 \\
\hline Upper neural epidermis & 32 & -56 & 5 & -14 \\
\hline $\begin{array}{l}\text { Lower neurai epidermis } \\
\text { upper epidermis of } \\
\text { petiole. }\end{array}$ & 9 & -41 & 7 & -20 \\
\hline Over parenchyma & 17 & -40 & 11 & -29 \\
\hline $\begin{array}{l}\text { Over central } \\
\text { collenchyma. }\end{array}$ & 46 & -115 & 5 & -17 \\
\hline $\begin{array}{l}\text { Over collenchyma of } \\
\text { wings. }\end{array}$ & 28 & -97 & 9 & -29 \\
\hline $\begin{array}{l}\text { Lower epidermis of } \\
\text { petiole over collen- } \\
\text { chyma. }\end{array}$ & 64 & -112 & 8 & -22 \\
\hline $\begin{array}{l}\text { Lower epidermis of } \\
\text { petiole over } \\
\text { parenchyma. }\end{array}$ & 20 & -64 & 14 & -42 \\
\hline $\begin{array}{l}\text { Epidermis of stem } \\
\text { over parenchyma. }\end{array}$ & 20 & -56 & 20 & -28 \\
\hline Over collenchyma & $28^{-}$ & -108 & 5 & -20 \\
\hline
\end{tabular}


2at. A. Phart. Sct., vot. 1, No.(1-2), Nov. 1992

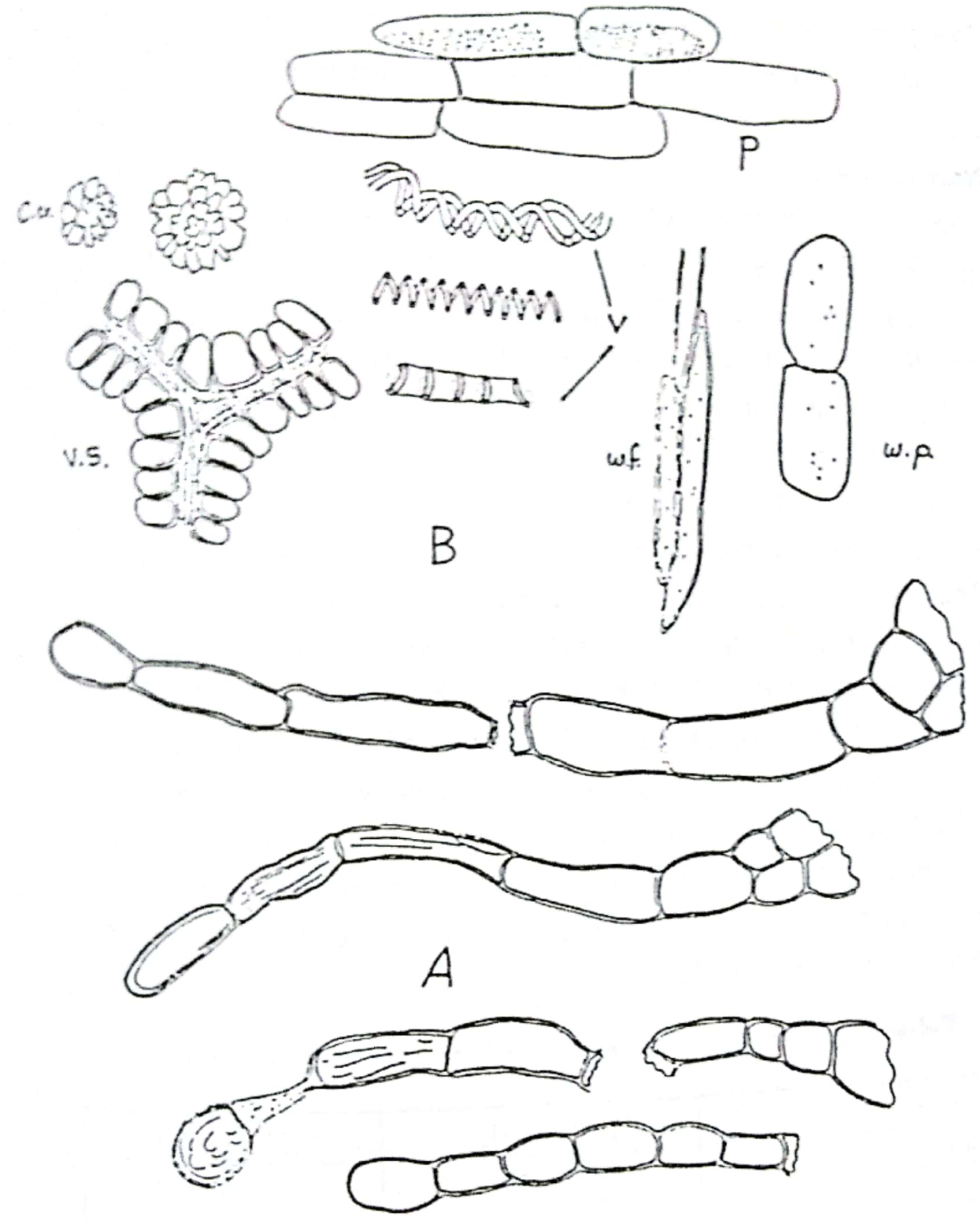

(A1! $\times 440$ )

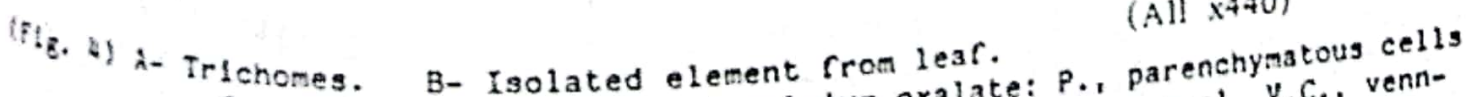
C.cr., Cluster crystals of calclum oxalate: P., parenel. V.C., vennconta!n sandy crystals of calclum oxalate: V., Kylen vessel, Hood parenchya. ation with clubshaped of calctun oxalat fiber; H.P., Hood parenchym., Wood 


\section{Pericycle:}

The pericycle of the vascular bundles of the midrib, petiole (Fig. 2, B \& $3, \mathrm{~B}$ ) and the stem (Fig. 5, B \& $6, \mathrm{~B}$ ) are formed of moderately thick. walled collenchymatous cells.

\section{Vascular tissue:}

The vascular bundles of the leaf (Fig. 2,B) young stem , (Fig. $5, B$ ) and young root (Fig . 8, B) consist of cellulosic phloem of thin - walled elements, xylem formed of lignified spiral, annular, pitted and reticulate vessels 8 to $53 \mu \mathrm{D}$, and thin walled cellulosic parenchyma. In old stem (Fig. 6,B) and old root (Fig. 9), the phloem is formed of moderatelly thick walled cellulosic elements, the cambium is indistinct, and the xylem is wholly lignified. It consists of wood fibres, vessels, few tracheids, tracheidal vessels and wood parenchyma, wood fibres (Fig. 7,A) have thick lignified pitted walls, wide lumen and acute to blunt or forked apices.

Vessels ( Fig. 7, A ) are annular, pitted or reticulate. Tracheids and tracheidal vessels ( Fig. 7, A ) are few with numerous bordered pits. Wood parenchyma (Fig. 7, A) is diffused, formed of polygonal, axially elongated cells with moderatly thick pitted, lignified walls. The medullary rays (Fig. 7 , A) are uniseriate being cellulosic in the phloem and lignified in the xylem. In the root, the outer rings of vascular bundles are embedded in a layer of thick wall, lignified pitted cells.The dimensions of vascular tissue are shown in table (2).

\section{Table (2) : Dimensions of Vascular Tissue in Microns}

\begin{tabular}{|l|c|c|}
\hline The element & " L" Length & " D" Diameter \\
\hline 1. Wood fibre & $188-352$ & $8-37$ \\
2. Vessel & & $35-69$ \\
3. Tracheidal vessel & $85-205$ & $11-25$ \\
4. Tracheids & $80-240$ & $8-24$ \\
5. Wood parenchyma & $56-200$ & $8-41$ \\
6. Medullary rays & $93-187$ & $22-46$ \\
\hline
\end{tabular}




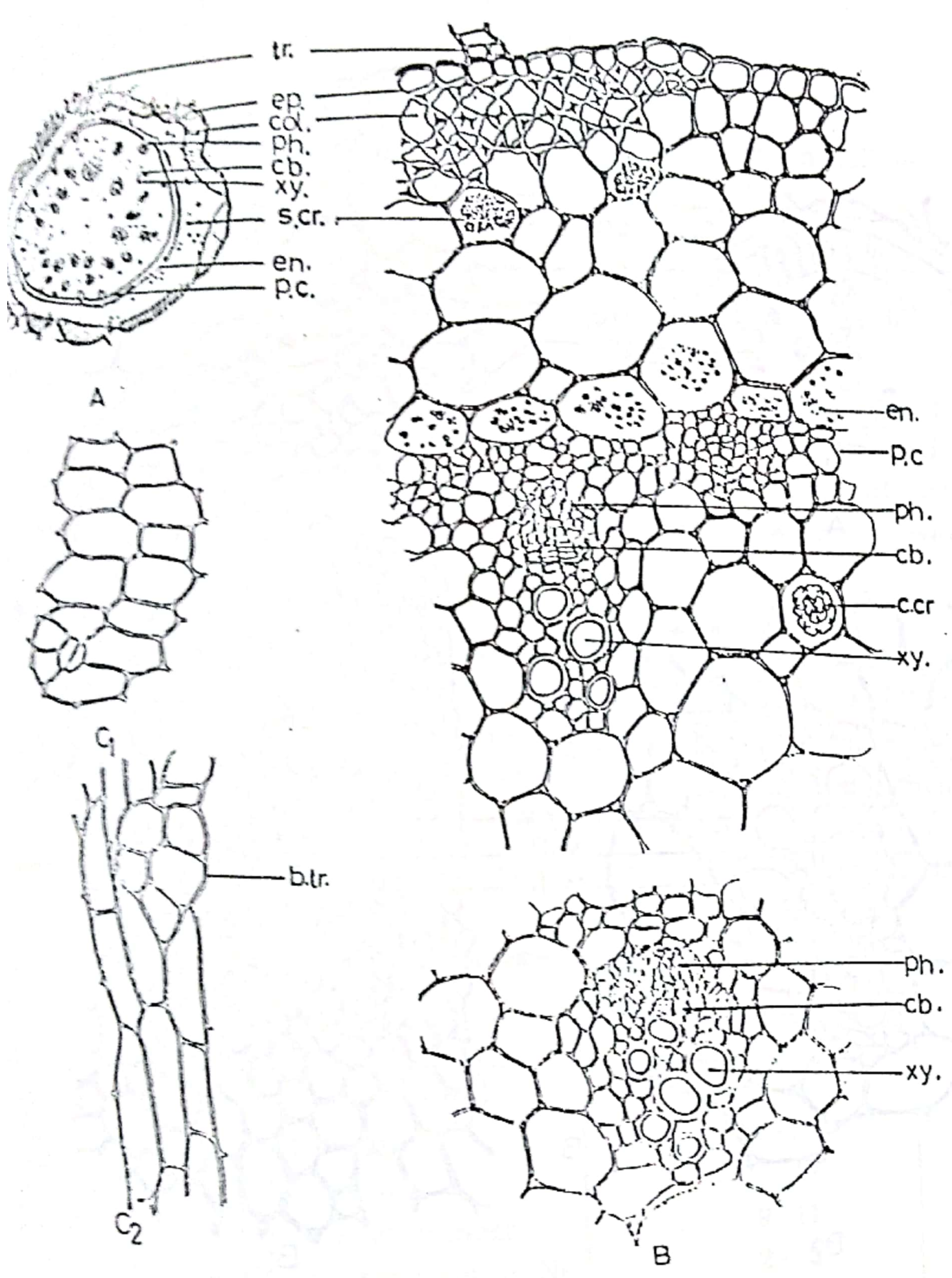

\footnotetext{
(4.5. 5) 2- Diagran or T.S. in young stem 2- Diagran or T.S. in young sten $\quad$ B- $C_{2}$ : Epldermal cells over rid
$C_{1}$ :Epideral cells between ridges b. tr., base of trichomes; Cb., Cambiunt Col., Collencepldermis, P.c., Cluster crystal or calcium oxalate; en., entodernis, epryals of calclum perleyclic collenchyma; ph.. phloem;

oxrlate; tr., trichomes xy., xylem.

(Ax 44, B $\left.\times 196, C_{1} \times 208, C_{2} \times 208\right)$
} 

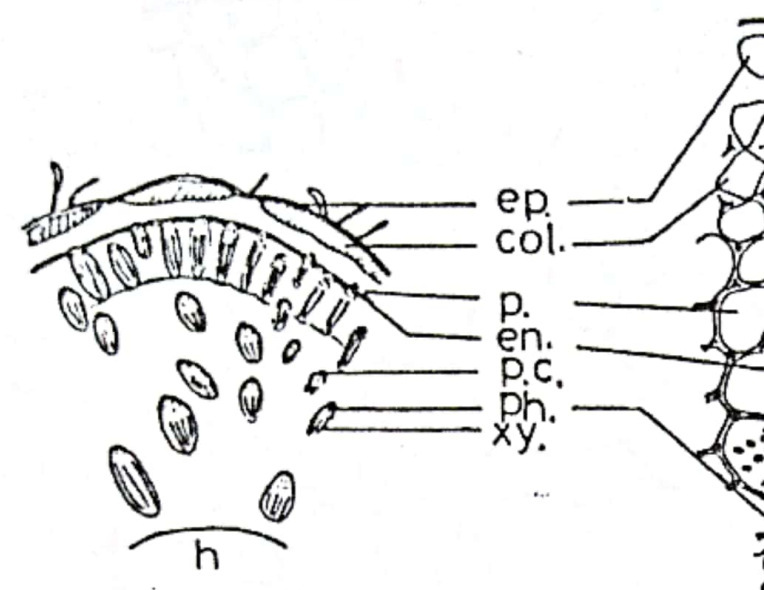

A

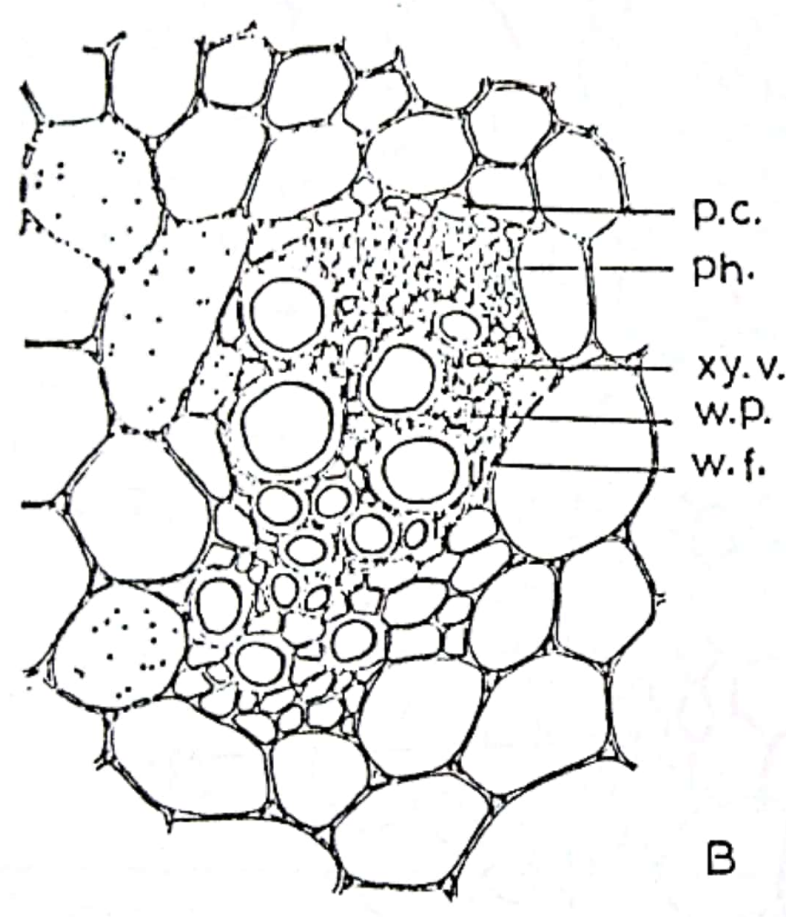

$\mathrm{B}_{2}$

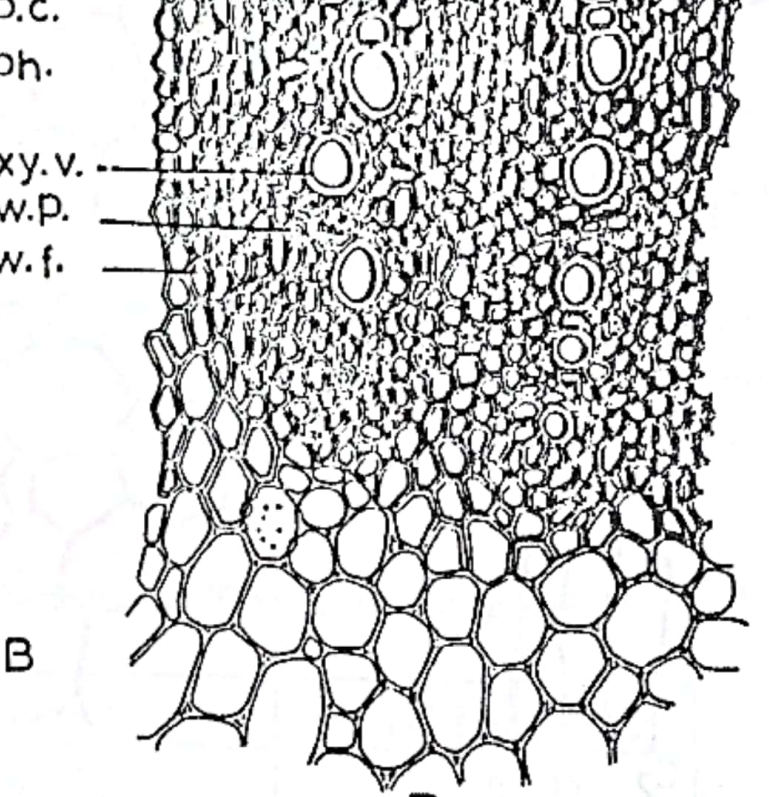

B1

(F/g. 6) A- Dingrnm of T.S. in old nt.am. $B_{1}$ in the outer part

B- Dotaluad of T.S. In bld at.nm.

Col., Collenchyma; en., endodermis., ep., epldermis; P., parenchyma; P.C., Pericycllc collenchyma; Ph., Phloem; w.f., Wood flbre; W.P., Wood parenchyma; Xylem vessels; Xy., Xylem.

(All $\times 212$, except $A \times 28$ ) 


$$
\text { gat. t. Pham. Sci., Vot. 2, No. }(1-2), \text { Nov. } 1992
$$

pith :

The pith is parenchymatous in young stem showing a hollow core in the old stem and contain sandy crystals of calcium oxalate. Poridan : It is present in the root (Fig. 8, B \& 9 ).

The cork : is formed of 4 to 6 rows of polygonal radially arranged cells with suberised walls; they measure 29 to $81 \mu \mathrm{L}$, and 23 to $52 \mu \mathrm{H}$.

The phelloderm : (Fig. 8,B \& 9 ) is wide, formed of parenchymatous cells containing simple or $/$ and compound starch granules and sandy crystals of calcium oxalate. Successive irregular rings of separate vascular bundles being formed in phelloderm with subsequent lignification in the region of outer 3 rings.

\section{Hesophyll :}

The mesophyll (Fig. 2,C) is isobilateral with one row of columnar palisade cells , below each epidermis , and measure 6 to $29 \mu$ in length and 2 to $8 \mu$ in diameter. The spongy tissue is narrow formed of loose chlorenchma, but around the veins there is a sheath of cubical clubshaped parenchymatous cell, measuring 10 to $26 \mu$ in length and 5 to $28 \mu$ in breadth. Some mesophyll cells contain sandy or cluster crystals of calcium oxalate 20 to 56 $\mu \mathrm{D}$ and starch granules.

Table (3): The numerical values of the leaf

\begin{tabular}{|c|c|}
\hline Items & value \\
\hline 1- Stomatal index: & \\
L.Epidermis . & $28-30$ \\
U.Epidermis & $15-17$ \\
2- Vein - islet number & $9-11$ \\
3- Veinlet termination No. & $2-3$ \\
4- Palisade ratio : & $9-11$ \\
U. palisade & $11-13$ \\
L. palisade & \\
\hline
\end{tabular}



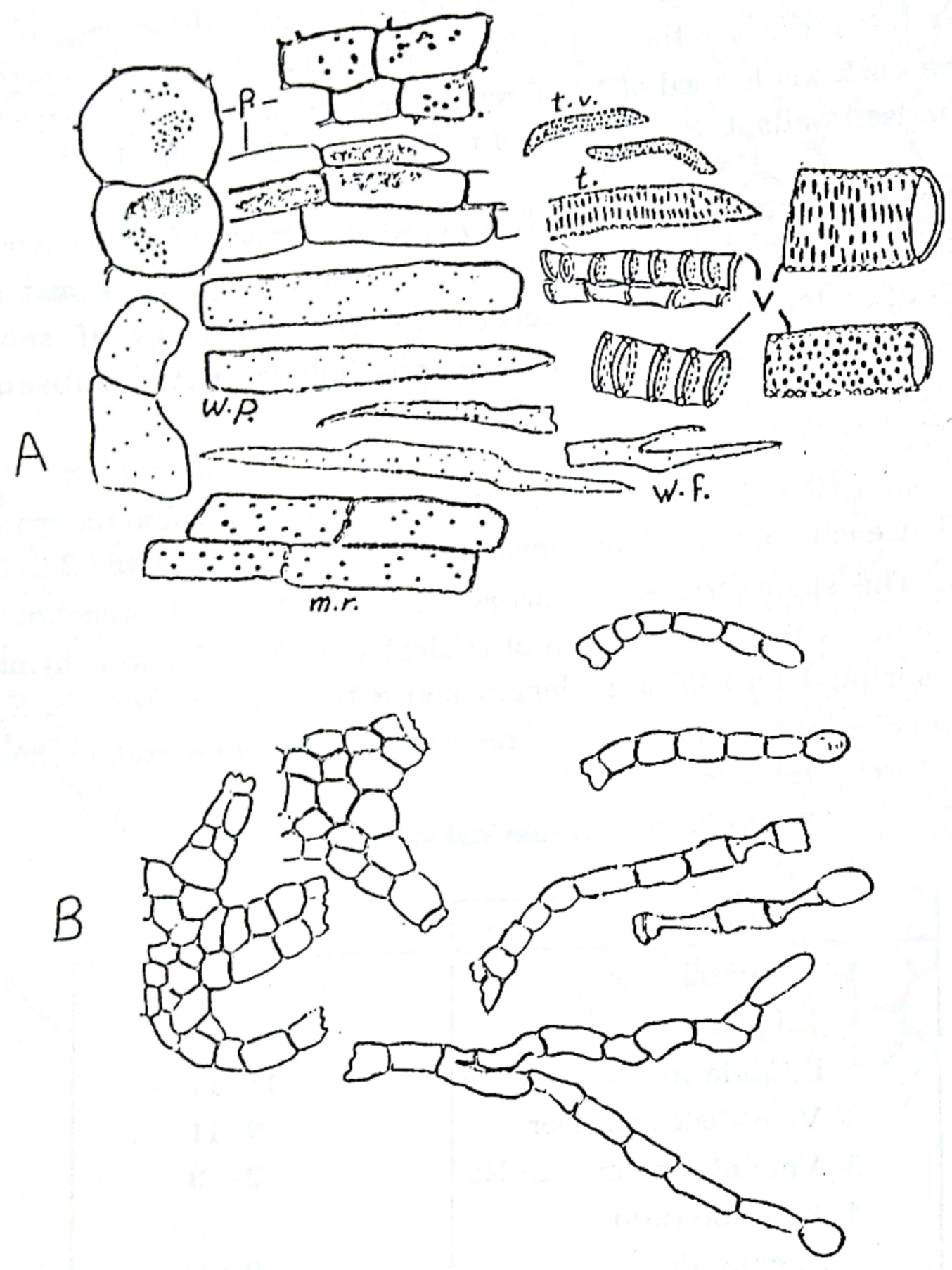

(Fig. 7) A- Isolated elements of stem B- Trichomes of stem M.r., Medullary ray; p., parenchyma contain sandy crystal of calcium oxalate and starch; t., tracheid;t.v., tracheidal vessel; V., Vessel; W.f., Wood fibre; W.P., Wood parenchyma. 


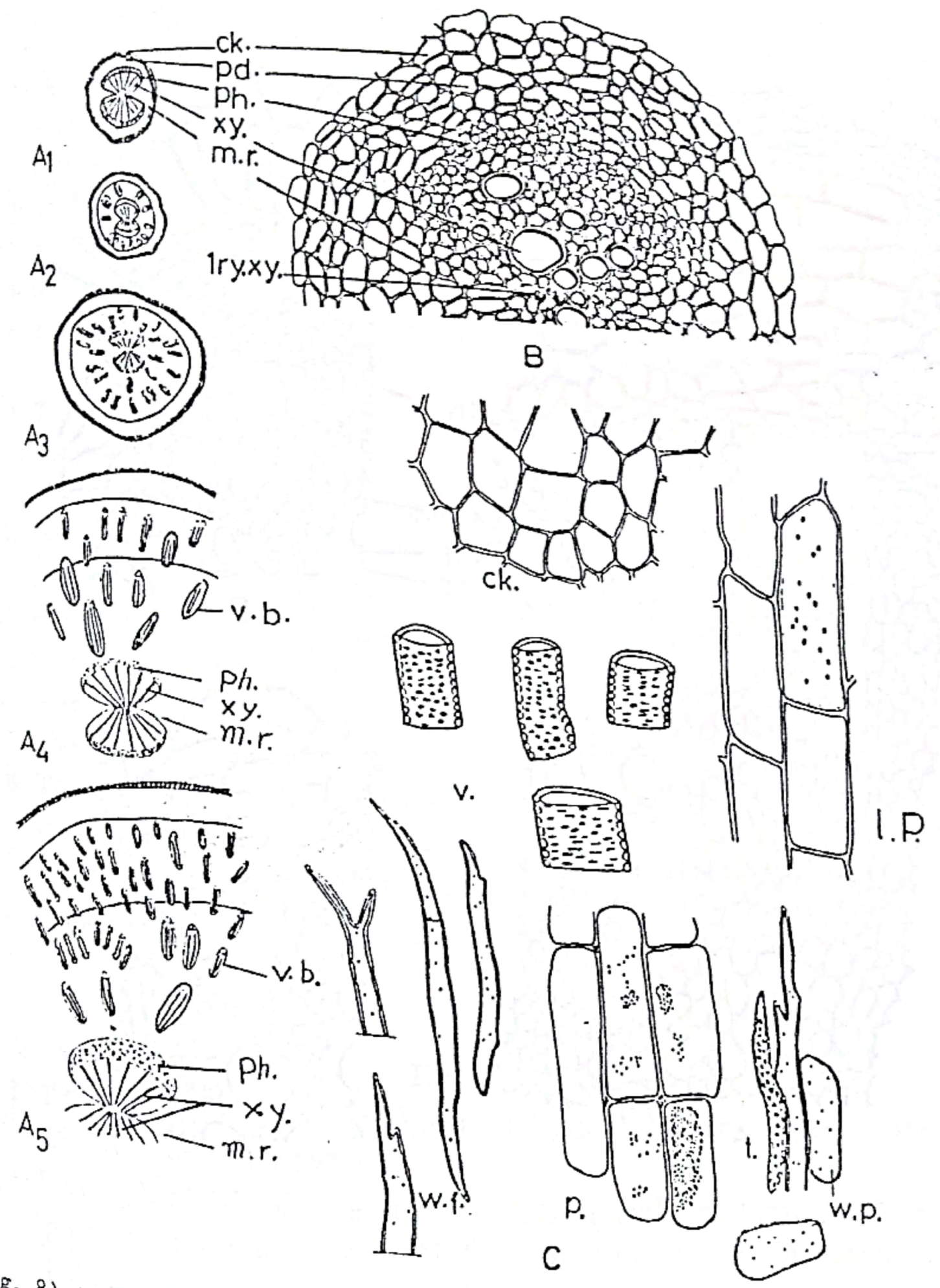

(Fig. 8)

$A_{1}$ - Diagram of T.S. of young root

$\mathrm{B}^{1}-\mathrm{A}_{5}$ Steps of anomalous secondry thickening of root

C - Detailed T.S. of young root

- Isolated elements of the root

Ck., Cork; L.P., Lignified phelloderm; P., parenchymatous cells

contain sandy crystals of calcium oxalate; p d., phelloderm; ph.,

phloem; V., Vessels; V.b., Vascular bundle; 1 ry.xy., primary xylem; Xy., Xylem.

$$
\left(A_{1} \times 36, A_{1}-A_{5} \times 16, B \times 224, C \times 224\right)
$$




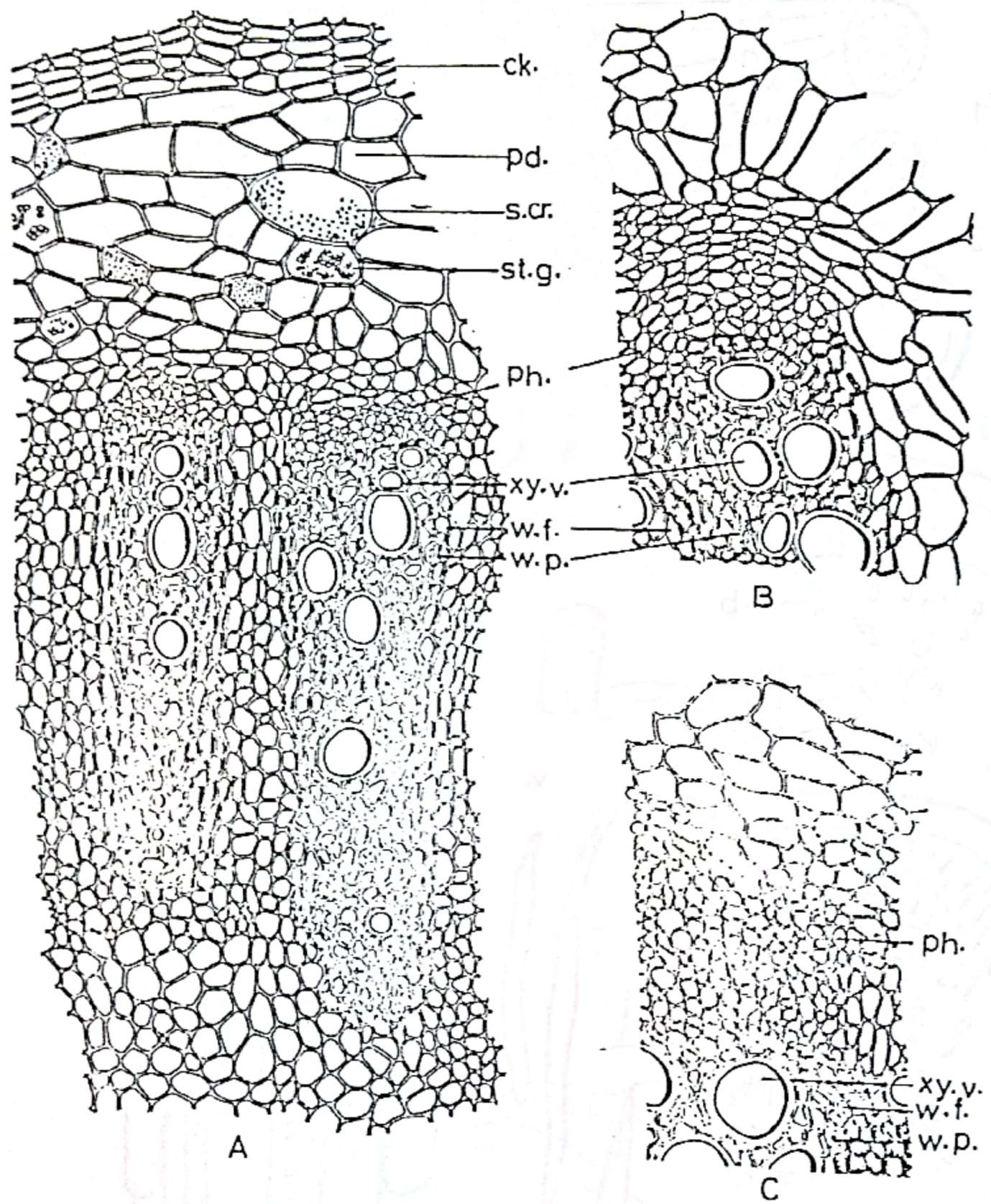

(Fig. 9) Detailed transverse section of old root.

(All $\times 216)$

A - In the outer part.

B - In the median vascular bundie.

$C$ - In the central vascular bundle.

Ck., Cork; Pd., Phelloderm; Ph., Phloem; S.cr., Sandy crystals o calcum oxalate; St.g., Starch granules; W.f., Wood fibre; W.p., Wood parenchyma; Xy., Xylem; Xy. V., Xylem vessel. 
$9 \cdot$ $209 \cdot$

J. Pharm. Sci., Vol. 1, No. (1-2), Nov. 1992

\section{CONCLUSION}

As a result of this study the following diagnostic features were found: 1. The plant is an annual herb attaining $3 \mathrm{~m}$. in height, with alternate leaves and cylindrical stem which carry terminal spikes.

2. Leaf is green, hairy, petiolate, ovate, lanceolate with entire margins and acute apex .

3. Root is fusiform, tap with many lateral rootlets.

4- The leaf is iso-bilateral and the midrib with an arc of 1 to 7 collateral v.bs and an inverted v.b.

5- The epidermal cells of the leaf and stem are polygonal with straight or wavy occasionally beaded anticlinal walls, covered with thin smooth cuticle and showing anomocytic stomata.

6. Numerous non-glandular trichomes are present on epidermis of leaf and stem,bing multicellular uniseriate ends with a long terminal cell covered with thin smooth cuticle. Glandular trichomes have multicellular uniseriate, biseriate and multiseriate branched stalk and unjcellular head.

7. Pericycle is collenchymatous.

8- The vascular tissue of the stem and root exhibit anomalous secondry thickening showing wide irregular rings of v.bs.

9. Wood fibres are lignified and pitted, vessels showing spiral, annular, pitted and reticulate thickening.

1. Tackholm REFERENCES Ed., p. $130-137$ (1974).

2- Perry , L.M." Medicinal Plants of East and Southern Asia", Atributed properties ad uses; the MIT press Combridge ,Massachusetts and London, England , pp. 8 - 12 (1980).

3- Sarg,T.M; Abd El-Aziz, E.M;.Salem, S.A and Zayed R.A; (Phytochemical Investigation of Amaranthus Chlorostachys willd., Growing in Egypt; Zag.J. Pharm.Sci, in press (1992). 
4- Dassanayaka , M.D., Edt., " Flora of Ceylon ", Oxford and IBH Publishing Co., New Delhi, Calcutta, Vol . 1, pp 1-57 (1980).

5- Metcalfe,C.R . and Chalk,L. " Anatomy of the Dicotyledons in Relation to Taxonomy with Notes on Economic Uses",Oxford University Press, Amenttous, London, E.C.U. Glasgow, New York, Toronto,Vol.11, pp.1062 - 1072 (1950):

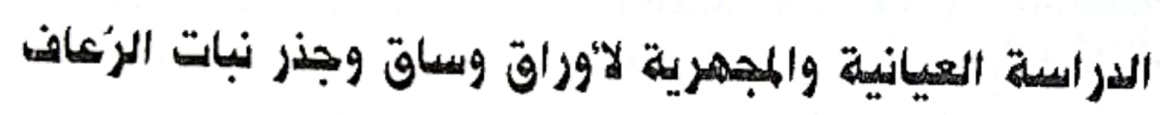

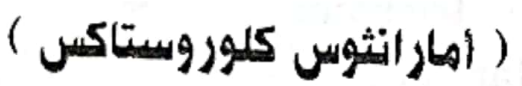

طه هصطفي سرج، احسان هحمو د عبد العزيز ، سالم عبد الهنعم سالم المارس وراويه عبد الهادى زايد

$$
\text { قسم العقاقير - كلية الصيدلة - جاهعة الزتازيت - عصر }
$$

سبق أن فام الباحئون بدراسة كبميائية لنبات الرُعاف الذي ينمو في مصر وقد أمكن فصل خلات الليبيول والليبيون ومادتين إستر اليفاتي والالفا سبينا ستيرول وألفا سبينا ستيرول جلوكوزيد وبيتا سيتو ستيرول جلوكوزيد والروتين والكورستين وصابونين ومواد نتروجينية

لذا فقد رؤي أن يثم دراسة الصفات العيانية والمجهرية لهذا النبات حتي يسهل الثعرف الكرلن

$$
\text { ناعدية مثل الكولين. }
$$$$
\text { عليه سواء في حالته الصحيحة أو علي هيئة مسحوف . }
$$

تتضمن هذه الدراسة الفحص العياني والمجهري لأوراق وساق وجذر هذا النبات . 